\title{
Identification of Mycobacteria Using Polymerase Chain Reaction and Sputum Sample
}

\author{
Hyung Seok Jang
}

Department of Pathology, Hanyang University Medical Center, Seoul 133-792, Korea

\section{객담을 이용한 Mycobacteria의 검출과 중합효소 연쇄반응의 민감성 비교}

장형석

한양대학교 서울병원 병리과

\begin{abstract}
Although Mycobacterium tuberculosis complex strains remain responsible for the majority of diseases caused by mycobacterial infections worldwide, the increase in HIV (human immuno deficiency virus) infections has allowed for the emergence of other non-tuberculous mycobacteria as clinically significant pathogens. M. tuberculosis was detected by two-tube nested polymerase chain reaction (PCR) and non-tuberculous mycobacteria was detected by PCR-restriction fragment length polymorphism (RFLP) with Msp I. Result of niacin test is equal to result of two-tube nested PCR after culture for M. tuberculosis. In this study, acid fast bacilli stain (AFB. stain) $>2+$ case, Detection of Mycobacteria is similar to result before culture and after culture. AFB. stain $<1+$ case, result of mycobacteria is distinguished. Conclusionly, these results suggest that identification of mycobacteria must go side by side both culture and PCR for more fast and accuracy.
\end{abstract}

Keywords: Mycobacterium tuberculosis, nontuberculous mycobacteria, acid fast bacilli stain, Polymerase chain reaction, PCR-restriction fragment length polymorphism

This is an Open Access article distributed under the terms of the Creative Commons Attribution Non-Commercial License
(http://creativecommons.org/licenses/by-nc/4.0) which permits unrestricted non-commercial use, distribution, and reproduction in any medium, provided the original work is properly cited.

Copyright (C) 2015 The Korean Society for Clinical Laboratory Science. All rights reserved.
Corresponding author: Hyung Seok Jang Department of Pathology, Hanyang University Medical Center, Seoul 133-792, Korea Tel: 82-2290-8898

E-mail: himylife@hanmail.net

Received: March 20, 2015

Revised: None

Accepted: April 9, 2015

\section{서 론}

항산성균(Mycobacterium)은 acid fast bacilli (AFB)라고도 하 며 보통 염색으로는 쉽게 염색되지 않으며 가온하여 일단 염색이 되면 산이나, 알코올, 알카리에 강하고 탈색이 되지 않는 성질을 가 지고 있으므로 항산성(acid fastness) 또는 항산성균(AFB)이라고 한다.

항산성균중에는 Mycobacterium 균속인 Mycobacterium tubersulosis (결핵균), Mycobacterium leprae (나균), atypical mycobacteria (비정형 결핵균)과 약한 항산성균으로 Nocardia,
Gordona, Tsukamurella 및 Rhodococcus가 있다.

결핵 감염은 아직까지 전 세계에서 높은 유병률과 사망의 주요 원인이 되고 있으며, 이중 결핵균(Mycobacterium tuberculosis, $\mathrm{MTB})$ 은 비말에 의해 전파되며 흡입된 소수의 균이 폐포표면에 부 착되면 폐포 큰포식세포에 의해 탐식되어 증식하기 시작한다. 감염 후 숙주내의 정상 면역력을 가진 개체이면 활성화된 $\mathrm{T}$ 림프구와 큰 포식세포가 주축이 되는 세포개재 면역이 발현된다. 그 결과 tuberculin 양성이 되고 균이 증식하고 있는 허파조직이 반고형의 괴사, 즉 건락괴사가 일어나 그 속의 균들이 대식구로부터 유리된 다. 반고형의 치즈괴사병변이 연화되어 액화하면 기관지로 결핵균 
이 배출되면서 결핵의 증상이 나타난다.

또한 비결핵 mycobacteria (nontuberculous mycobacteria, $\mathrm{NTM}$ )는 최근 임상 검체에서 분리빈도가 증가함에 따라 분리 균주 의 임상적 의의도 중요시 되고 있다(Falkinham J.O. 1996; Kennedy et al. 2003) (Sakatani M. 1999). 후천성 면역결핍증 (aquired immune deficiency syndrome, AIDS)이나, 종양, 이식 등으로 면역력이 저하된 환자들에서 발병빈도가 계속증가하고 있 다(Horsburgh et al. 1991). 비결핵 항산균 폐질환의 원인균 분포 는 지역에 따라 차이를 보이는데 서구와 일본에서는 $\mathrm{MAC}$ (mycobacterium avium complex)에 이어 M. kansasii 가 두 번째 로 흔한 비결핵항산균 폐질환의 원인균임에 비해, 지금까지의 국내 보고와 유사하게 본 연구에서도 MAC에 이어 M. abscessus 가 두 번째로 흔한 NTM으로 나타났다(Choi et al. 2013).

신속 발육균의 종류로는 M. abscessus, M. fortuitum, M. chelonaei, 등이 속하며, 특히 M. abscessus는 주로 연부조직 감염 이나 폐 감염을 일으키며 병원성이 강한 것으로 보고되어있다 (Metchock et al. 1999) (Ingram et al. 1993). M. abscessus에 의 한 감염의 경우 대부분의 항결핵제에 내성을 나타내고 종 내에서도 항균제 감수성이 달라 일반적으로 항균제 감수성 검사가 요구된다.

결핵균과 비결핵균의 분리빈도가 증가함에 따라 정확한 동정이 요구되고 있는데, 대표적인 검사법으로 도말검사(AFB stain), 배양 법, 분자생물학적 방법을 들 수 있다.

Mycobacteria를 감별 동정하는 도말검사는 기법이 간편하고 저렴하여 쉽게 할 수 있고 결과가 빨라 환자관리에 편리할 뿐 아니 라 이 방법으로 진단되는 환자가 바로 결핵을 전파하는 전염원이라 역학적 측면에서도 중요하다. 그러나 직접도말검사는 객담 $1 \mathrm{ml}$ 내 에 $10^{4}$ 개 이상의 균이 있어야 검출이 가능할 정도로 감수성이 낮고, 결핵 유병률이 높은 지역에서는 문제가 안 되지만 결핵이 많지 않 은 지역에서는 도말표본에서 보이는 항산성균이 결핵균이 아닌 경 우가 많아서 특이성도 문제가 되고 있다.

반면에 균 분리배양검사는 균 동정이 가능해 특이성도 높고 비 교적 소수의 균도 검출이 가능해 감수성도 높은 편이지만, 검사과 정이 복잡해 비용도 많이 들고 검사결과가 $3 \sim 4$ 주 이상 걸리는 단 점이 있다.

따라서 요즘은 뛰어난 감수성과 특이성에 이어 결과의 신속함을 가진 분자생물학적 방법인 중합효소 연쇄반응(polymerase chain reaction, PCR)도 사용하고 있으나 PCR은 비용과 검체 내 균수 크 기를 알려주지 못하는 단점이 있다.

이에 본 연구에서는 mycobacteria의 동정에 있어, 보다 정확하 고 신속하게 동정하기 위해서 항산성균 양성검체를 이용하여 균 분 리 배양검사와 PCR 방법을 비교해 보았다.

\section{재료 및 방법}

\section{1. 검체}

2011년 8월부터 2012년 3월까지 서울시 소재의 한 대학병원에 서 결핵환자로 의심되는 객담 검체를 Ziehl-Neelsen's 법에 따라 항산성 염색한 결과 trace 이상의 양성으로 결과가 판독된 266개의 검체를 사용하였다.

\section{DNA 추출}

\section{1) 객담 검체에서 DNA 추출}

객담 검체를 $4 \% \mathrm{NaOH}$ 로 동량 첨가하여 잘 섞은 다음 15 분후 $3,000 \mathrm{rpm}$ 에서 20 분간 원심분리한 후 상층은 버린다. 침전물에 증류수 $1 \mathrm{ml}$ 을 가하고 잘 섞은 후 microcentrifuge tube에 $1 \mathrm{ml}$ 를 넣고 $12,000 \mathrm{rpm}$ 에서 3 분간 원심분리후 상층은 버리고 침전물을 추출한다. 각 침전물에 Insta Gene Matrix (Bio-RAD, Hercules, California, USA) $200 \mu$ 를 첨가 후 잘 섞는다. 이후 $56^{\circ} \mathrm{C}$ heat block에 30 분 방치한 후 8 분간 꼻인 다음 즉시 ice-water에 식힌 후 12,000 rpm에서 3 분 원심분리하여 상층액을 DNA template 로 사용하였다. 즉시 사용하지 않을 시에는 $-20^{\circ} \mathrm{C}$ 에 보관한다.

\section{2) 배양 후 집락 검체에서 DNA 추출}

$3 \%$ Ogawa 배지에서 자란 균집락 검체는 $200 \mu 1$ 의 Insta Gene Matrix (Bio-RAD, Hercules, California, USA)액에 풀어 $56^{\circ} \mathrm{C}$ heat block에 30 분 방치한다. 이후 8 분간 끊인 다음 즉시 ice-water 에 식힌 후 $12,000 \mathrm{rpm}$ 에서 3 분 원심분리하여 상층액을 DNA template로 사용하였다.

\section{Polymerase chain reaction (PCR)}

1) 결핵균과 비정형 결핵균을 구분하기 위한 two-tube nested $\mathrm{PCR}$

(1) First PCR

선택된 primers가 든 반응 혼합액(mixture, $45 \mu \mathrm{l})$ 에 Insta Gene Matrix에 의해 추출된 DNA 산물 $5 \mu$ 를 가하고 Thermal cycler (GeneAmp PCR system 9700, Perkin-Elmer cetus, Boston, Massachusetts, USA)를 이용해 표적 DNA를 증폭 합성하 였다.

반응 혼합액 조성은 M. tuberculosis complex (M. tuberculosis, M. bovis)에 특징적으로 존재하는 IS 6110 의 $547 \mathrm{bp}$ 를 증폭하기 위하여 Primer로 pr-5인 5'-CTC AAG GAG CAC ATC AGC-3'와 pr-6인 5'-TCA TAG GAG CTT CCG ACC-3'를 각각 $1 \mu$ 씩 첨가 하고, Thermohilus aquaticus (Taq.) DNA중합효소(Perkin-Elmer 
Cetus Corp., Norwalk, USA)를 $0.25 \mu \mathrm{l}$, dNTP (dATP, dCTP, dGTP, dTTP) 각각 $1.0 \mu$ l씩, 10x Reaction buffer $5.0 \mu \mathrm{l}$, 증류수 $33.75 \mu 1$ 를 첨가하였다.

반응주기는 pre-denaturation $94^{\circ} \mathrm{C} 5$ 분, denaturation $94^{\circ} \mathrm{C}$ 1 분, annealing $60^{\circ} \mathrm{C} 1$ 분, elongation $72^{\circ} \mathrm{C} 1$ 분을 30 cycle을 시 행하였다.

\section{(2) Second PCR}

선택된 primers가 든 반응 혼합액(mixture, $48 \mu$ l)에 First PCR product $2 \mu$ 를 가하고 Thermal cycler (GeneAmp PCR system 9700, Perkin-Elmer cetus, Boston, Massachusetts, USA)를 이 용해 표적 DNA를 증폭 합성하였다.

반응 혼합액은 조성은 $M$. tuberculosis complex ( $M$. tuberculosis, M. bovis)에 특징적으로 존재하는 IS 6110의 285 $\mathrm{bp}$ 를 증폭하기 위하여 Primer로 pr-7인 5'-CTA CGG TGT TTA CGG TGC CC-3'와 pr-8인 5'-TAG GCG TCG GTG ACA AAG GC-3'를 각각 $1 \mu 1$ 씩 첨가하고, Taq. DNA 중합효소(Perkin-Elmer Cetus Corp., Norwalk, USA)를 $0.25 \mu \mathrm{l}$, dNTP (dATP, dCTP, dGTP, dTTP) 각각 $1.0 \mu \mathrm{l}$ 씩, 10x Reaction buffer $5.0 \mu$, 증류수 $36.75 \mu 1$ 를 첨가하였다.

반응주기는 pre-denaturation $94^{\circ} \mathrm{C} 5$ 분, denaturation $94^{\circ} \mathrm{C}$ 1 분, annealing $62^{\circ} \mathrm{C} 1$ 분, elongation $72^{\circ} \mathrm{C} 1$ 분을 30 cycle을 시 행하였다.

반응이 끝난 다음, 반응물 $10 \mu 1$ 를 취해 $2 \%$ agarose gel에서 전 기영동한 후 ethidium bromide ( $\mathrm{EtBr}, 0.5 \mu \mathrm{g} / \mathrm{ml}$ 로 염색하여 302 $\mathrm{nm}$ 의 UV transilluminator (Spectroline Co., New York, USA)로 DNA bands를 관찰하였다.

\section{2) 비정형 결핵균 동정을 위한 PCR-RFLP}

NTM 동정을 위하여 추출된 DNA산물에 mycobacteria에 공통 적으로 존재하는 $r p o B$ 유전자 중 일부인 $360 \mathrm{bp}$ 를 증폭하기 위하 여 primer로 RPO1 인 5'-TCA AGG AGA AGC GCT ACG A-3'와 RPO2 인 5'-GGA TGT TGA TCA GGG TCT GC-3'를 PCR하였다.

증폭된 PCR산물 $15 \mu$ l에 MSp I (Boehringer Manheim Biochemicals, Germany) $0.5 \mu \mathrm{l}(10 \mathrm{U} / \mu \mathrm{l}), 10 \mathrm{x}$ Msp I buffer 2 $\mu 1$, 멸균된 증류수 $2.5 \mu 1$ 를 넣어 $20 \mu$ l의 혼합물을 잘 섞어주고, $13,000 \mathrm{rpm}$ (약 10,000 g)에서 3 5 초간 원심분리 하였다.

$37^{\circ} \mathrm{C}$ 항온수조에서 90 분간 반응한 후 PRA (PCR-RFLP assay) size marker와 각 효소반응액(10 $\mu$ l)을 $4 \%$ metaphor TBE agarose gel (FMC, Bioproducts, Maine)에 점적한 후 $100 \mathrm{~V}$ 에서 $60 \sim 75$ 분간 전기영동 탱크에 얼음을 담아 전기영동하였다.
Gel을 EtBr로 염색한 후 UV transilluminator로 분절편을 확인 하였다. 결과판독은 mycobacteria 동정 algorithm을 참고하여 균 을 동정하였다(Lee et al. 2000).

\section{결 과}

\section{1. 항산성 염색 양성검체의 $\mathrm{PCR}$}

객담 검체에서 $\mathrm{DNA}$ 를 추출한 후, 결핵균과 비정형결핵균을 구 분하기 위하여 two-tube nested PCR과 $r p o B$ gene의 $360 \mathrm{bp}$ 부 분을 증폭하는 $\mathrm{PCR}$ 을 시행하였다.

우선, M. tuberculosis complex에 특징적으로 존재하는 IS 6110 의 특정부위인 $547 \mathrm{bp}$ 와 $285 \mathrm{bp}$ 부분을 증폭한 two-tube nested PCR을 시행하였다. 그 결과 MTB는 $285 \mathrm{bp}$ 부분에 band 를 나타내고(Fig. 1), band가 나타나지 않은 검체는 NTM 검체로 잠 정 결론 내렸다. 이 후, 잠정 NTM 검체는 mycobacteria에 공통적 으로 존재하는 $r p o B$ 유전자 중 일부인 $360 \mathrm{bp}$ 부분을 증폭한 후, $M s p$ I을 첨가 PCR-RFLP를 시행하여 NTM 동정결과를 확인할 수 있었다(Fig. 2).

항산성 염색 결과가 trace인 48 검체로 $\mathrm{PCR}$ 을 시행한 결과 $\mathrm{MTB}$ 가 $1, \mathrm{NTM}$ 이 0, 음성이 47 검체에서 확인되었고, 항산성 염색 결과 가 $1+$ 인 16 검체에서는 MTB가 $5, \mathrm{NTM}$ 이 0, 음성인 검체가 11 로 확인되었다. 또한 항산성 염색 결과가 2+인 104 검체에서는 MTB 가 $100, \mathrm{NTM}$ 이 3, 음성 1 검체로 확인되었고, 항산성 염색 결과가
$\mathrm{M}$
$1 \quad \mathrm{~N} \quad \mathrm{P}$

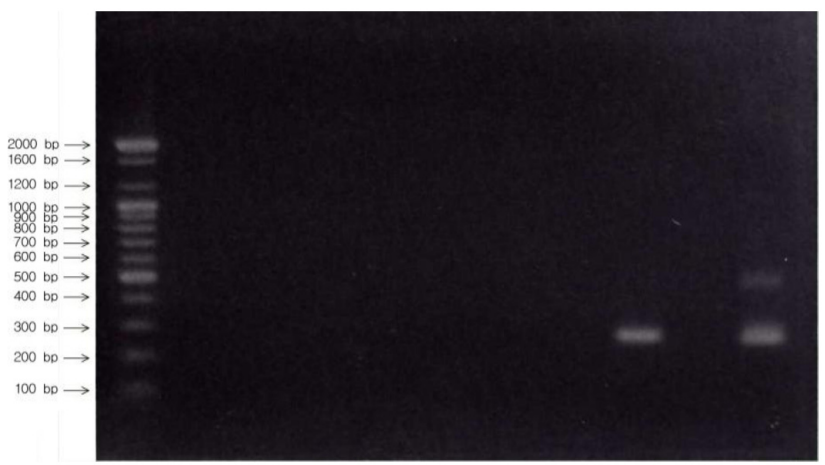

Fig. 1. Detection of Mycobacterium tuberculousis from acid fast bacillus smear-positive sputum specimens by two-tube nested $P C R$. PCR products were run on a $2 \%$ agarose gel stained with Ethidium Bromide (EtBr). Lanes; M, DNA size marker (Bioneer, Alameda, California, USA), the DNA ladder consists of 13 double stand DNA fragments ranging in sizes from 100 to $1,000 \mathrm{bp}$ in $100 \mathrm{bp}$ increments, and additional fragments of 1,200, 1,600, $2,000 \mathrm{bp}$. The 500, 1,000 and 2,000 bp bands are two to three times brighter for easy identification; 1, M. tuberculousis; N, negative control, distilled water; $\mathrm{P}$, positive control, M. tuberculosis (ATCC 25177 standard strain). 


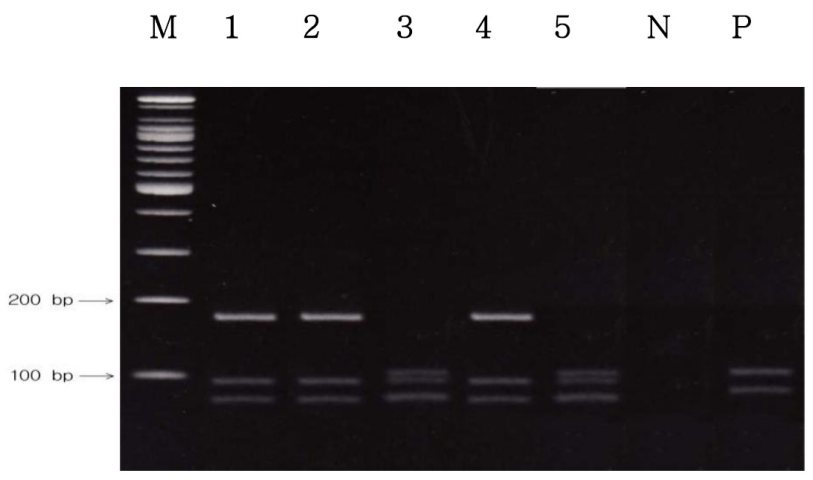

Fig. 2. PCR RFLP analysis of acid fast bacillus smear-positive sputum specimens. Amplified DNAs were digested with MSP I and run on a $4 \%$ metaphore agarose gel. Lanes; M, PCR-RFLP size marker; 1, M. intracellulare; 2, M. intracellulare; 3, M. abscessus; 4, M. intracellulare; 5, M. abscessus; N, negative control, distilled water; $\mathrm{P}$, positive control, $M$. avium.

$3+$ 인 98 검체에서는 MTB가 $96, \mathrm{NTM}$ 이 2, 음성인 검체가 0으로 확인되었다.

\section{2. 항산성 염색 양성검체의 균 분리배양 과정을 통한 $\mathrm{PCR}$}

항산성 염색 trace 이상인 검체의 순수분리 동정을 위하여 3\% ogawa 배지에 배양을 시행하였다. 항산성 염색 결과가 trace인 48 검체로 배양한 결과 양성인 검체가 47 , 음성인 검체가 1 , 항산성 염 색 결과가 $1+$ 인 16 검체에서는 양성이 15 , 음성이 1 검체이며, 항 산성 염색 결과가 $2+$ 인 104 검체에서는 양성이 104 , 음성이 0 , 항 산성 염색 결과가 $3+$ 인 98 검체에서는 양성이 98 검체, 음성이 0 으로 확인되었다

항산성 염색 trace이상인 검체를 배양한 집락(colony)의 DNA 를 추출하여 결핵균과 비정형결핵균을 구분하기 위하여 two-tube nested PCR과 $r p o B$ gene의 $360 \mathrm{bp}$ 부분을 증폭하는 PCR을 시행 하였다.

우선, M. tuberculosis complex에 특징적으로 존재하는 IS 6110 의 특정부위인 $547 \mathrm{bp}$ 와 $285 \mathrm{bp}$ 부분을 증폭한 two-tube nested PCR을 시행하였다. 그 결과 MTB는 $285 \mathrm{bp}$ 부분에 band 를 나타내고(Fig. 3), band가 나타나지 않은 검체는 NTM 검체로 결 론내렸다. 이 후, NTM 검체는 mycobacteria에 공통적으로 존재 하는 $r p o B$ 유전자 중 일부인 $360 \mathrm{bp}$ 부분을 증폭한 후(Fig. 4), Msp I을 첨가 PCR-RFLP를 시행하여 NTM 동정결과를 확인할 수 있었 다(Fig. 5).

항산성 염색 결과가 trace인 48 검체로 PCR을 시행한 결과 $\mathrm{MTB}$ 가 $40, \mathrm{NTM}$ 이 7, 음성이 1 검체에서 확인되었고, 항산성 염색 결과 가 $1+$ 인 16 검체에서는 $\mathrm{MTB}$ 가 $12, \mathrm{NTM}$ 이 3, 음성인 검체가 1 으 로 확인되었다. 또한 항산성 염색 결과가 2+인 104 검체에서는

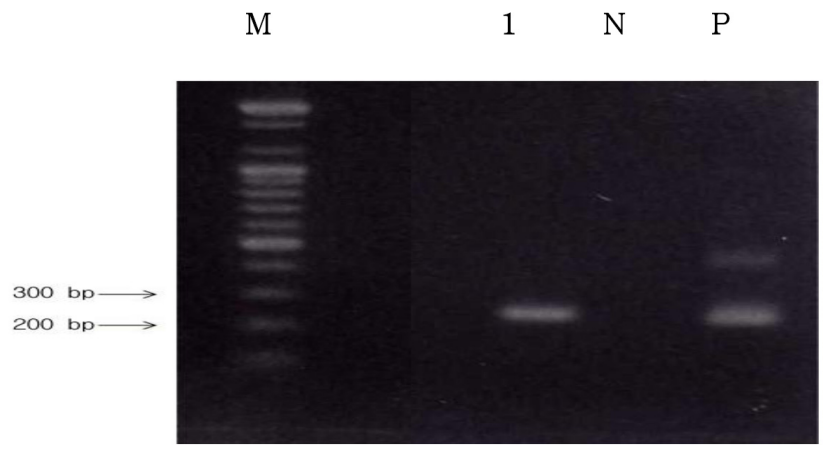

Fig. 3. Detection of Mycobacterium tuberculousis from cultured colony of acid-fast bacillus smear-positive specimens by two-tube nested PCR. PCR products were run on a $2 \%$ agarose gel. Lanes; M, DNA size marker; 1, M. tuberculousis; N, negative control, distilled water; P, positive control, M. tuberculosis (ATCC 25177 standard strain).

$\begin{array}{llllllllllllllllllll}1 & 2 & 3 & 4 & 5 & 6 & 7 & 8 & 9 & 10 & 11 & 12 & 13 & 14 & 15 & 16 & \mathrm{~N} P & \mathrm{M}\end{array}$

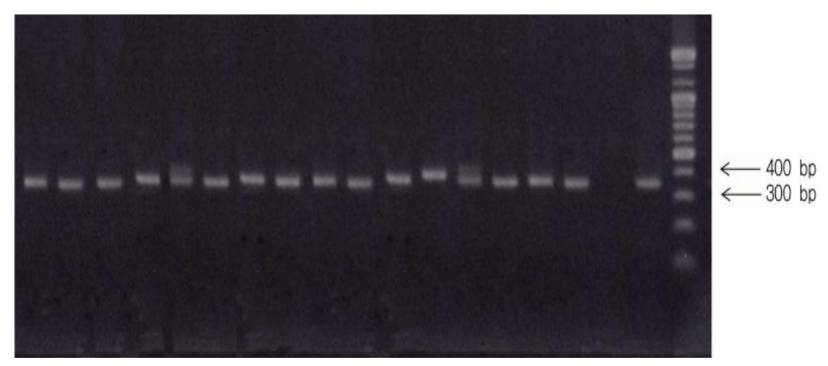

Fig. 4. PCR amplification of the $r p o B$ gene from cultured colony of acid-fast bacillus smear-positive specimens. PCR products were run on a $2 \%$ agarose gel. Lanes; $M$, DNA size marker; 1 16, positive; $\mathrm{N}$, negative control, distilled water; $\mathrm{P}$, positive control, M. tuberculosis (ATCC 25177 standard strain).

MTB가 $100, \mathrm{NTM}$ 이 4, 음성 0 검체로 확인되었고, 항산성 염색 결 과가 3+인 98 검체에서는 $\mathrm{MTB}$ 가 $96, \mathrm{NTM}$ 이 2, 음성인 검체가 0 으로 확인되었다.

\section{고 찰}

항산균 염색을 이용한 객담 도말검사는 결핵균과 비정형 결핵균 을 구별할 수 없다는 제한점이 있고(American Thoracic Society 2000), 균 분리배양검사는 시간이 오래 걸린다는 단점이 있어, 본 연구에서는 이러한 제한점을 가진 기존의 검사법을 대신하여 분자 생물학적 방법인 $\mathrm{PCR}$ 을 이용하여 균 분리배양 검사와 비교하여 보 았다.

객담검체에서 $\mathrm{DNA}$ 를 추출하여 PCR한 결과, 항산성균 염색이 trace와 $1+$ 에서는 낮은 동정률을 보인 반면, $2+$ 이상에서는 대부 분 동정되는 것을 확인할 수 있다. 반면 배양을 통해 집락의 $\mathrm{DNA}$ 를 추출하여 PCR한 결과는 항산성균 염색의 강도와는 상관없이 대부 
A

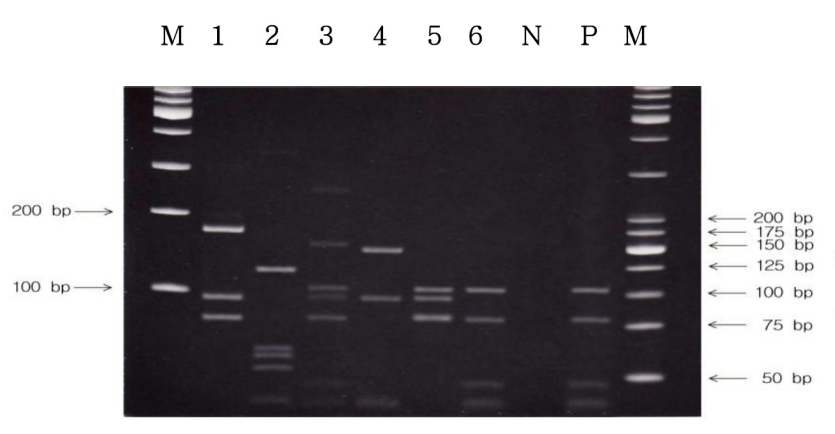

C
B

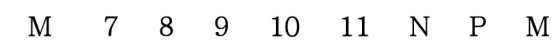

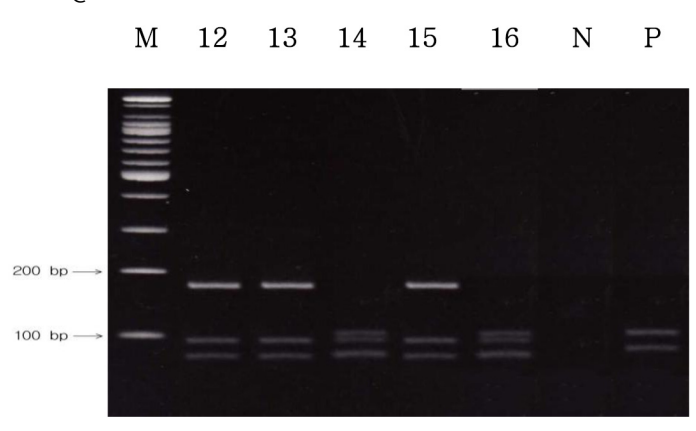

Fig. 5. (A) PCR RFLP analysis using cultured colony of acid-fast bacillus smear-positive specimens. Amplified DNAs were digested with Msp I and run on a 4\% metaphore agarose gel. Lanes; M, PCR-RFLP size marker, 25/100 bp mixed DNA ladder; 1, M. intracellulare; 2, M. intracellulare; 3, M. abscessus; 4, M. intracellulare; 5, M. abscessus; 6, M. avium; N, negative control, distilled water; P, positive control, M. avium. (B) PCR RFLP analysis using cultured colony of acid-fast bacillus smear-positive specimens. Amplified DNAs were digested with Msp I and run on a 4\% metaphore agarose gel. Lanes; M, PCR-RFLP size marker, 7, M. avium; 8, M. intracellulare; 9. M. abscessus; 10, M. fortuitum II; 11, M. fortuitum II; N, negative control, distilled water; P, positive control, M. avium. (C) PCR RFLP analysis using cultured colony of acid-fast bacillus smear-positive specimens. Amplified DNAs were digested with Msp I and run on a 4\% metaphore agarose gel. Lanes; M, PCR-RFLP size marker; 12, M. intracellulare; 13, M. intracellulare; 14, M. abscessus; 15, M. intracellulare; 16, M. abscessus; N, negative control, distilled water; P, positive control, M. avium.

분 동정되는 것을 확인 할 수 있다.

이 결과로 항산성균 염색이 $2+$ 이상인 경우는 배양전후 $\mathrm{PCR}$ 동 정결과에 차이가 거의 없고, $1+$ 이하에서만 현격한 차이가 있음을 확인할 수 있다.

균 분리배양 검사 결과 항산성균 양성 검체들이 대부분 집락을 형성하는데 항산성균 trace와 $1+$ 검체에서 각각 1 개씩 배양되지 않 았으며, 이는 객담검체에서 DNA를 추출하여 PCR것과 배양을 통 해 집락의 $\mathrm{DNA}$ 를 추출하여 $\mathrm{PCR}$ 한 것으로 어느 곳에서도 동정되 지 않았다. 이는 검체가 오염으로 인한 것인지, 검체가 소량으로 인 한 것인지로 추측되는 문제점으로 남아있다.

균 분리배양 후 MTB를 확인하기 위해서 niacin test를 실시한 결과 항산성 염색 trace인 경우 40 검체, $1+$ 인 경우 12 검체, $2+$ 인 경우 100 검체, $3+$ 인 경우 96 검체가 niacin test 양성임을 확인할 수 있었다. 이 결과와 집락의 $\mathrm{DNA}$ 를 추출하여 PCR한 MTB가 일치 함을 확인할 수 있었다.

본 실험에서 항산성균 염색이 2+이상인 경우는 배양전후 $\mathrm{PCR}$ 동정결과에 차이가 거의 없고, trace인 경우는 배양 전 PCR 결과가
$2 \%$ 에서 배양 후 $97.9 \%$ 까지, $1+$ 인 경우는 배양 전 PCR 결과가 $31.2 \%$ 에서 배양 후 $93.7 \%$ 까지 높일 수 있었다. 또한 배양만으로는 $\mathrm{MTB}$ 의 동정은 가능하지만 NTM의 동정이 가능하지 않으므로 배 양검사와 $\mathrm{PCR}$ 검사 모두를 병행하므로써 신속하고 보다 정확한 검 사결과를 내는데 도움될 것이다.

항산성염색 trace 이상의 양성 266 검체를 임의로 추출한 것임 으로 MTB와 NTM의 분리빈도에 따른 통계처리를 나타내는데 실 험에 사용된 전체 검체수의 부족한 문제점이 있으며, 동정된 16 개 의 NTM 검체 역시 발병률이 높은 NTM 검체를 나타내는데 적절하 지 못한 문제점이 있다.

여기서는 다양한 종류의 NTM 검체가 발견되었는데, 우선 객담 검체에서 $\mathrm{DNA}$ 를 추출하여 $\mathrm{PCR}-\mathrm{RFLP}$ 를 이용하여 $M$. intracellulare 와 M. abscessus가 동정 되었으며, 배양을 통해 집락의 $\mathrm{DNA}$ 를 추 출하여 PCR-RFLP를 이용한 것에는 M. intracellulare, $M$ terrae, M. avium, M. gordonaetype I, M. abscessus, M. fortuitum II 등 이 동정되었다. 또한 객담검체에서 $\mathrm{DNA}$ 를 추출하여 PCR-RFLP를 이용하여 동정된 NTM균의 항산성 염색의 강도는 2+이상에서 나 
타남을 확인할 수 있고, 배양을 통해 집락의 $\mathrm{DNA}$ 를 추출하여 PCR-RFLP를 이용한 동정된 NTM 균은 항산성균 염색의 강도와는 무관했다.

Mycobacteria에는 약 70 여종이 있으며 이중 일부는 폐결핵, 피 부와 연조직 감염, 림프절감염, 파종성(산재성)감염을 일으키고 있 어 정확한 동정이 요구되고 있다(Vareldzis et al. 1994) (Wolinsky et al. 1992).

이번 실험에서 동정된 NTM 균중 M. abscessus는 신속발육균에 속하며 병원성이 강한 것으로 보고되어 있다(Metchock et al. 1999). 국내에서도 면역저하 환자의 증가에 따라 M. abscessus에 의한 감염이 증가하고 있으며, M. abscessus에 의한 감염의 경우 대부분의 항결핵제에 내성을 나타내고, 종내에서도 항균제 감수성 이 달라 일반적으로 항균제 감수성이 요구된다. 최근에는 연부조직 감염에서 진행하여 균혈증을 보인 환자의 검체를 포함하여 피부조 직과 객담, 혈액 등으로부터 M. abscessus를 분리 동정하여 감염 경로와 경과, 치료, 및 균의 특성에 대하여 보고된 바도 있다. 이에 균 분리배양을 하는 데 있어 신속발육균이 MTB 검체에 섞일 수 있 으므로 배양기간을 6주 이상 충분히 둔 후, MTB와 NTM 동정을 병 행하는 것이 최선의 방법일 것이다. 또한 이전에는 NTM 균주들을 단순히 오염균으로만 여겼지만, 최근에는 인체감염의 원인균으로 의의가 증가하고 있어, NTM 균주의 신속하고 정확하게 진단할 수 있는 검사법의 개발이 필요하며, 국내 임상 검체에서 새롭게 동정 되는 NTM 균주에 대한 연구가 필요한 실정이다(Choi etal. 2014).

위에 결과들로 MTB과 NTM 동정 모두에 있어 실험에 사용된 검 체수가 분리빈도를 나타내기에는 부족하므로 좀 더 많은 수의 비교 실험이 지속적으로 연구되어야 할 것이며, 균 분리배양 검사나 $\mathrm{PCR}$ 의 어느 한 가지 방법만 이용할 것이 아니라 두 가지 검사를 모 두 병행함으로써 좀 더 신속하고 정확한 검사결과에 도움이 될 것 이라고 생각된다.

\section{요 약}

결핵(Mycobacterium tuberculosis, MTB) 감염은 아직까지 전 세계에서 높은 유병률과 사망의 주요 원인이 되고 있으며 비정형 결핵(nontuberculous mycobacteria, NTM)은 최근 후천성 면역 결핍증(AIDS)이나, 종양, 이식 등으로 면역력이 저하된 환자들의 임상 검체에서 분리빈도가 증가함에 따라 분리 균주의 임상적 의의 가 중요시 되고 있다. 이에 항산균 염색을 이용한 객담 도말검사는 결핵균과 비정형 결핵균을 구별할 수 없다는 제한점이 있고, 균 분 리배양검사는 시간이 오래 걸린다는 단점이 있어, 본 연구에서는 이러한 제한점을 가진 기존의 검사법을 대신하여 분자생물학적 방 법인 중합효소 연쇄반응(polymerase chain reaction, PCR)을 이
용하여 균 분리배양 검사와 비교하여 보았다. Mycobacteria를 동 정하는데 항산균 염색과 $3 \%$ ogawa 배지를 이용하였고, 균 분리배 양 후 M. tuberculosis를 확인하기 위해서 niacin test를 실시한 결 과 집락의 $\mathrm{DNA}$ 를 추출하여 $\mathrm{PCR}$ 후 동정된 M. tuberculosis와 niacin 양성이 일치함을 확인할 수 있었다. 또, 이 실험에서 항산성 균 염색이 $2+$ 이상인 객담검체와 집락검체 각각에서 $\mathrm{DNA}$ 를 추출 하여 결핵균을 동정하는 방법으로 M. tuberculosis complex에 특 징적으로 존재하는 insertion sequence (IS) 6110의 특정부위인 $547 \mathrm{bp}$ 와 $285 \mathrm{bp}$ 부분을 증폭한 two-tube nested polymerase chain reaction을 시행하였고, 비정형 결핵균 동정법으로는 mycobacteria에 공통적으로 존재하는 rpoB 유전자 중 일부인 $360 \mathrm{bp}$ 부분을 증폭한 후, 제한효소 Msp I을 첨가 PCR-restriction fragment length polymorphism (RFLP)을 시행하였으며, 결핵균 과 비정형 결핵균 모두 동정율에 거의 차이가 없었다. $1+$ 인 경우는 객담검체에서 PCR한 결과가 $31.2 \%$ 에서 집락검체의 PCR한 결과 93.7\%까지 결핵균과 비정형결핵균의 동정율이 높아졌고, trace인 경우 객담검체에서 $\mathrm{PCR}$ 결과가 $2 \%$ 에서 집락검체에서 $\mathrm{PCR}$ 한 결 과가 $97.9 \%$ 까지 결핵균과 비정형 결핵균의 동정율을 높일 수 있었 다. 이 실험에서 항산성균 염색 $1+$ 이하 일때 객담검체와 집락검체 로 PCR을 실시하면 결핵균과 비정형 결핵균의 동정율에 차이가 있 고, 배양만으로는 결핵균의 동정은 가능하지만 비정형 결핵균의 동 정이 가능하지 않으므로 배양검사와 $\mathrm{PCR}$ 검사 모두를 병행하므로 써 보다 신속하고 정확한 검사결과를 내는데 도움 될 것이다.

\section{Acknowledgements: None \\ Funding: None \\ Conflict of interest: None}

\section{References}

1. American Thoracic Society. 2000. Diagnostic standards and classification of tuberculosis in adult and children. Am J respir Crit Care Med 161:1376-1395.

2. Choi S R, Kang M J, Park G-H, Kim D-H, Jeong D-W, Seo E-H, et al. Species Identification of Nontuberculous Mycobacteria (NTM) by PCR-Restriction Fragment Length Polymorphism (PRA) of the rpoB Gene from Three Hospitals of BusanKyeongnam Area, Korean J Clin Lab Sci. 2013, 45(2):48-53

3. Choi Y-I, Kim H-Y. Usefulness of PCR to Mycobacterium Tuberculous and Nontuberculous Mycobacteria from Paraffinembedded Tissues. Korean J Clin Lab Sci. 2014, 46(2):47-53

4. Horburgh CR Jr. 1991. Mycobacterium avium complex infection in the acquired immunodeficiency syndrome. $N$ Engl $J$ Med, 324:1332-8.

5. Ingram CW, Tanner DC, Durack DT, Kernodle W, Corey GR. 1993. Disseminated infection with rapidly growing myco- 
bacteria. Clin Infect Dis, 16:463-71.

6. Kennedy MP, O'Conor TM, Ryan C, Sheehan S, Cryan B, Bredin C. 2003. Nontuberculous mycobacteria: incidence in Southwest Ireland from 1987 to 2000. Respir Med, 97:257-63.

7. Lee HY, Park HJ, Cho SN, Bai GH, Kim SJ. Specific identification of mycobacteria by PCR-restriction fragment length polymorphism of the rpoB gene. J. Clin. Microbiol. 2000;37:17141720

8. Metchock BG, Nolte FS, Wallace RJ, Jr. 1999 . Chapter 25. Mycobacterium. In:Patrick RM, Ellen JB, Michael AP, Fred CT, Robert HY, editor. Manual of Clinical Microbiology. 7th ed.
washington:ASM press, 399-437.

9. Sakatani M. 1999. Nontuberculous mycobacteriosis. the present status of epidemiology and clinical studies. Kekkaku, 74:377-84.

10. Vareldzis BP. Grosset J. Kantor ID. Crofton J. Laszlo A. Felten M. 1994. Drug resistant tuberculosis. Laboratory issues(World Health Organization recommendations). Tubercle lung Dis, $75: 1-7$.

11. Wolinsky E. 1992. Mycobacterial disease other than tuberculosis. Clin Infect Dis, 15:1-12. 